\title{
Language, Press, and Indonesian Nationalism
}

\author{
Miftahul Habib Fachrurozi \\ Program Studi Pendidikan Sejarah Universitas Maret Surakarta \\ Universitas Islam Negeri Syarif Hidayatullah Jakarta Indonesia \\ Habibhmps1@gmail.com
}

\begin{abstract}
This paper will discuss relationship between language, the development of the press, and the emergence of Indonesian nationalism in the early twentieth century. Nationalism is a common consciousness of every individual in a community to achieve a common goal. Nationalism is the idea formed through a historical process. Therefore, the emergence of nationalism is influenced by various factors in a particular historical context. One of the factors influencing the emergence of Indonesian nationalism is the similarity of language. Language, especially the print language makes everyone who uses it has a similarity of shadows that make it connected to each other. The print language that encourages the emergence of Indonesian nationalism was "Bahasa Melayu Pasar" (Bazaar Malay language or Malay language). This language is widely used in various newspapers in Indonesia in the early twentieth century.

The development of Malay language in Indonesia was related to the development of the press. The development of the press was supported by the development of print capitalism in the Dutch East Indies. Print capitalism enabled a variety of printing products including press to spread to various regions of Dutch East Indies. The press changed Malay language from a mere lingua franca to a language with ideological and political meaning. The used of Malay language in various press made it as a common identity that united the diversity of various ethnic groups in Indonesia. This is the important role of language and the press as a lighter in the emergence of Indonesia's national consciousness in the early twentieth century.
\end{abstract}

Keyword—Language; Press; Nationalism; history; Batavia

\section{INTRODUCTION}

Indonesian nationalism was not something just present. Indonesian nationalism emerged as part of a historical process. Indonesian nationalism was a long process of identity formulation to glorify people [1, p. vii]. Such consciousness was not born out of a vacuum of history. The arbitrary treatment of the colonial government coupled with racial discrimination against the bumiputra (indigenous people) has triggered the birth of Indonesian national consciousness. Therefore, the effort of Indonesian human breeding was synonymous with the abolition of oppression and racial discrimination that had been

The struggle of the bumiputra to escape the oppression of the colonial government took a different form in every age. Before the twentieth century the struggles of the bumiputra relied more heavily on the physical struggle through wars inflamed by figures from different regions. At this time there emerged a number of heroes against the colonial government such as Kapitan Pattimura from Maluku or Prince
Diponegoro from Yogyakarta. In the beginning of $\mathrm{XX}$ century, the struggle through the field of action began to be abandoned and replaced with other forms of struggle.

One of the most popular forms of struggle in fighting for the liberation of the bumiputra in the early twentieth century was the way of the press. The use of the press as a means of struggle can not be separated from the emergence of educated bumiputra as a new intellectuals in the Dutch East Indies. Adam Ahmat's research on "Early History of the Press and Awakening of Indonesian Awareness" shows the important role of the press as a means of generating the social-political consciousness of the Indonesian nation in the early twentieth century. Ahmat Adam emphasized the importance of kemadjoean (progress) discourse in various newspapers as the starting point of Indonesia's national consciousness. Nevertheless, the research has not raised the importance of language in the process of forming Indonesian Nationalism. The role of language in the formation of national awareness of Indonesia is what will be described in this paper.

\section{METHODS}

This study uses historical research methods according to Kuntowijoyo, with stages (1) Selection of topics, (2) Heuristics (source collection), (3) Source criticism, (4) Interpretation, (5) Historiography [2, pp. 69-80]. The selection of topics is the stage for defining titles with certain considerations. Heuristics is the stage of collecting both primary and secondary sources for processing at a later stage. Source criticism is conducted to test the validity of physical and content resources. Interpretation is the stage of interpreting and understanding the sources that have been obtained. Historiography is the stage of preparation of all research based on the rules of historical writing.

\section{RESULTS AND DISCUSSIONS}

\section{A. Early Press History in Indonesia}

The development of the press in the Dutch East Indies could not be separated from the existence of the printing machine. The first printing machine in the Dutch East Indies was imported by Church missionaries in 1624 [3, p. 2]. However, the machine was used for the printing needs of official state documents. The first newspaper was printed in 1744. The newspaper was Bataviasche Nouvells printed by the VOC's official printing office [3, p. 4]. This was the starting point of press history in the Dutch East Indies. Broadly 
speaking the history of the press in the Dutch East Indies is divided into three stages. The first began in 1744- 1854, the second lasting from 1854-1907, and last began 1907-1945. Each round has its own distinctive features that distinguish one from the other. Characteristic of each of the round was also related to the spirit of the times and the socio-political dynamics that occurred at that time.

The first half, as discussed earlier, was marked by the publication of the Bataviasche Nouvelles newspaper in 1744 [4, p. 64]. Bataviasche Nouvelles became the first newspaper published in the Dutch East Indies. The involvement of the bumiputra in the press at this time was still very limited. The reason was the limitations of literacy among the bumiputra. VOC still monopolizes the press. The press at that time was still dominated by Europeans and Chinese. The language used by the press of the time was Dutch. In this era, the press was mostly used for the benefit of trade and missionaries.

The second era of Indonesian press history began in 1854 . This revolt began with the emergence of a Press Law published by the colonial government. The leniency of press activities began to take effect in this era. Slowly the bumiputra began to engage in various press activities at this time. A number of newspapers began involving the bumiputra in their production process even though ownership was still held by the Europeans $[1$, p.8, 22]. Some newspapers involving bumiputra include Soerat Chabar Betawie, published in 1858, then Bromartani published in Solo in 1865, then Bintang Timoer in Padang (1865), and Tjahaja Sijang in Minahasa (1868) [4, p.64]. In addition, the function of the press was also not limited to missionary and trade activities only. The press at this time showed a shift in function by beginning to showed the control function of the colonial government.

The last round (1907-1945) was marked by the birth of Medan Prijaji. Medan Prijaji has its own meaning in the history of the press. Medan Prijaji managed by Tirto Adhi Soerjo became the first newspaper to openly enter the political sphere. The entry of Medan Prijaji in this political sphere directly made the press a tool of resistance against the colonial government. The Medan Prijaji's way was classified as radical considering the ways of the bumiputra in fighting the colonial government are mostly still using physical ways. The ways that have been pioneered by Medan Prijaji was followed by various other newspapers. Along with the development of the era, the press has changed from just a means of conveying information into a political tool to realize the political aspirations of the bumiputra in the Dutch East Indies as well as to encourage the emergence of national awareness of Indonesia.

\section{B. Language, Press, and Indonesian Nationalism}

There are various definitions of Nationalism. Nationalism is generally defined as a love attitude to the homeland. Another definition mentions if nationalism is an awareness of the same destiny and with the people of the country. Nationalism can also be interpreted as an individual feeling as part of a political community and envisioned as something that is both inherently and sovereign in nature [5, p. 8]. Thus, nationalism can be interpreted as an individual consciousness as part of a community. As an implication of that, nationalism also implies a shared feeling between one member and the rest of the community. Nationalism ultimately awaken the individual about his being with other members of the community.

The press was the most appropriate medium for disseminating the idea of Indonesian nationalism in the early twentieth century. The rapid development of the press enabled more bumiputra, especially educated bumiputra to read newspaper. The similarity of this reading which will later develop into a collective consciousness as a nation. The press was the only medium that allows it to happen. The development of the press in the Dutch East Indies was closely linked to the development of print capitalism. Print capitalism is a capitalist venture in the field of printing that encourages the spread of printing products (including newspapers) as widely as possible to profit as much as possible [5, p. 56]. The Europeans in the Dutch East Indies viewed the field of printing as a promising economic undertaking. Print capitalism grew in the liberal economy (1870-1900). The press was an integral part of the developmental motives of print capitalism at that time [3, p. 68]. The logic of Capitalism allows printing products such as newspapers to be widespread throughout the Dutch East Indies. The newspaper editors seek to meet the information needs of potential customers. The trading information was the most sought-after information by the people in the Dutch East Indies at the end of the nineteenth century. Therefore, newspapers published at the time contain more trading information in the hope of attracting potential buyers.

Bahasa Melayu Pasar ("Bazaar Malay language" or "Malay language") was the most commonly used as communication language throughout the Dutch East Indies. The spread of Malay language did not occur naturally but has a political background. The colonial government basically did not want the indigenous people to speak Dutch $[6$, p. 53]. The used of the Malay language aimed to preserving Dutch dominance against the bumiputra ultimately contributed positively to the development of national awareness of Indonesia. Malay language became a very practical language to be used to communicate by the majority of ethnic groups in the Dutch East Indies. Malay language had been used in the field of trade [7, p. 47]. The used of Malay language was not only directed to an exclusive ethnicity, but also rather aimed at an inclusive bumiputra community. Such inclusive character was also a starting point for the emergence of early awareness of Indonesian nationality. According to Daniel Dakhidae [5, p. xxxii], the similarity of language usage becomes an important meaning in the projection of a nation's presence. The widespread used of Malay was part of the Indonesian nation-building process. A number of newspapers published in the early twentieth century such as Bintang Hindia and Medan Prijaji also used Malay language. The press became the main media in disseminating the use of Malay language among the bumiputra. This process, together 
with the development of progress discourse, shows the important role of the press in shaping the national consciousness of the Indonesian nation in the early twentieth century.

The various products of print capitalism have evolved into the media spreading the idea of the progress of the bumiputra. The logic of Capitalism that seeks to meet the needs of educated bumiputra made newspapers with the discourse of progress beginning to emerge and widespread in the Dutch East Indies. The spread of progress discourse through the newspaper has significance in the formation of the consciousness of educated bumiputa. The press that published in the morning or late afternoon will be read by many people at the same time. This reader's insight indirectly leaves newspaper readers connected to each other $[5$, p. 52]. The readers of the newspaper consume the same ideas that indirectly form a common mindset among readers. Press allowed readers to connect with each other even though they never actually met in real life. Press were able to form a collective consciousness for their readers. Thus, the collective consciousness of educated bumiputra in the Dutch East Indies in the early twentieth century was only able to form through the product of print capitalism such us newspapers or the press. The collective consciousness of the educated bumiputra later evolved into Indonesia's national consciousness.

One of the leading figures who played important role in the development of Indonesian nationalism was Abdul Rivai. Abdul Rivai popularized the term of the "bangsa Hindia" (Indian nation) in various articles in the Bintang Hindia newspaper $[8, \mathrm{p}$. 13]. The term used to distinguish the bumiputra with the koelit poetih or the Europeans [9]. The use of the term was surprising because the imagination of the unity of the bumiputra was still very strange in the Dutch East Indies in the early twentieth century. The use of the "bangsa Hindia" term in the Bintang Hindia gave awareness for the bumiputra to unite beyond the boundaries of race, ethnicity, and geography for the common progress of the bumiputra.

One of the things that was able to unite the bumpitra was the commonality of language. Abdul Rivai used Malay language as the medium of instruction in the Bintang Hindia. Abdul Rivai argued that Malay language was the right medium for disseminating his ideas. The unity of language desired by Abdul Rivai seems to have significance. Language unity became a link for multicultural bumiputra [7, p. 49]. Traditional bumiputra use their native language in their daily conversations. This created a gulf between various society in Dutch East Indies. The used of Malay language in the end was able to become the eraser of the barrier which restricted the interaction between various ethnic groups in the Dutch East Indies. The press was one of the medium to popularize the Malay language among bumiputra people.

Another figure who played important role in the development of Malay language as a language of unity was R.M. Tirto Adhi Soerjo. Tirto was the chief editor of a leading newspaper in the early twentieth century, Medan Prijaji. Medan Prijaji first published in 1907 and lasted until 1912. Medan Prijaji was the first newspaper in Indonesia that all members of the editorials come from the bumiputra. The language used in Medan Prijaji was Malay language. Medan Prijaji published by the publishing company N.V. Medan Prijaji [10, p. 49]. The company was founded by R. M. Tirto Adhi Soerjo and his colleague, Haji Mohammad Arsad. Thus, Medan Prijaji was the first newspaper in Dutch East Indies to be managed entirely by the bumiputra.

Tirto played an important role in providing a political sense for the Malay language. Malay language was a lingua franca for various society in the Dutch East Indies. Abdul Rivai later came up with the idea of "bangsa Hindia" using Malay language as a unifying language. Tirto made Malay language a means to build an ideological and political base. For Tirto, the press not only serves as a medium of trade or means of spreading the idea of progress, but it must also be politicized. Thus, language was no longer used as a means of communicating. Language was used as a means of glue as well as the birthplace of Indonesian national ideology.

Tirto through Medan Prijaji had an important role in encouraging the emergence of national awareness of Indonesia. This was seen in the slogan of Medan Prijaji, " "SOEARA bagai sekalian Radja-radja, Bangsawan asali dan fikiran, Prijaji dan saudagar Boemipoetra dan officier-officier serta saudagar- saudagar dari bangsa jang terperentah laenja, jang dipersamakan dengan Anaknegri, di seloeroeh Hindia Olanda" (The sounds for all kings, the original and thoughtful nobles, the elite bumiputra, employees, and traders of the ruled nation, to all indegenous people in the Dutch East Indies) [10, p. 47]. The slogan shows the existence of two groups of nations in the Indies, the "the ruling nation" and " the ruled nation". The concept of "the ruled nation" in the slogan of Medan Prijaji had a political meaning. The concept provided a collective identity for the various society in the Dutch East Indies who at that time experienced discriminatory and repressive measures from the colonial government. Through this collective identity, the feeling of the destiny and the awkwardness of the various society in the Dutch East Indies slowly began to emerge. The similarity of the fate of a nation had an important meaning in the process of national awareness formation of a nation. Otto Bauer stated that a nation may only arise as a result of a shared experience of the past [11, p. 370]. Medan Prijaji present to encourage awareness of the similarity of fate for the bumiputra. This is the significance of Medan Prijaji in the process of forming Indonesian nationalism.

Medan Prijaji successfully changed the Malay language from oral to written language. Malay language that develops into Indonesian language (Bahasa) actually an oral language and not a written language. Bahasa was used only as a social language and does not have a time structure in it. Bahasa was different from the Javanese language which used as a mantra in ceremonies or markers of one's status in social structure. Through the press, the Bahasa was transformed into a conceptual language that was more than just a social 
language. The press successfully transformed the social language into written language used as a common identity marker. The concept of "the ruled nation" in Medan Prijaji became the confirmation of the change.

The Rivai and Tirto's struggle through the press road affirms the importance of the role of language in the formation of the Indonesian nationalism. The idea of Rivai's "bangsa Hindia" and the "the ruled nation" of Tirto were an identity that united the various society in the Dutch East Indies. The language chosen to express the concept was Bahasa. Certainly if the Bahasa did not appear and develop in the world of the press, then the Indonesian nation will never be the same as we now know. Therefore, it was not wrong to say that Indonesian nationalism is actually print nationalism. Indonesian nationalism was indeed a struggle to convert oral Indonesian into printed language in various newspapers.

\section{CONCLUSIONS}

Indonesian nationalism was an idea born from the historical process. Nationalism can be interpreted as an individual consciousness as part of a community and in this case was the nation of Indonesia. Indonesian nationalism was a reaction to the repression of the colonial government against the bumiputra in the Dutch East Indies. The repression of the colonial government created the consciousness of the bumiputra as a colonized nation. This awareness became the starting point of the Indonesian liberation struggle from the repression of the colonial government.

The development of the press and the used of Malay language were two important factors that encouraged the early development of Indonesian nationalism. The development of the press was always related to the socio-political conditions of society in that time. Kemadjoean (progress) discourse spread by the Indonesian press in the early XX century became the starting point of the development of Indonesian nationalism as an effort of glorification and humanization the bumiputra. The role of the press in spreading the national awareness of Indonesia was not only limited to the dissemination of discourse kemadjoean but also on the spread of Malay language that develops into Bahasa. The use of Bahasa in the press was not only serves as a glue means but also served as a means to build an ideological and political base. Through the used of the concept of "the ruled nation" in Medan Prijaji newspaper the collective consciousness of the bumiputra was slowly beginning to wake up.

Feelings of destiny and awkwardness of the various society in the Dutch East Indies, which became the main condition of the growing sense of Nationalism slowly began to emerge. That was the most important contribution of the press and language to the rise of Indonesian nationalism in the early twentieth century.

\section{REFERENCES}

[1] RahzenTaufik, Dahlan, and Muhidin M, Rumah Bahasa dan Identitas Bersama. Seabad Pers Kebangsaan. Yogyakarta, 2008.

[2] Kuntowijoyo, Pengantar Ilmu Sejarah. . . Yogyakarta: Tiara Wacana, 2013.

[3] Ahmat Adam, Sejarah Awal Pers dan Kebangkitan Kesadaran Keindonesiaan. Jakarta: Hasta Mitra, 2003.

[4] Andreas Harsono, Agama Saya Adalah Jurnalisme. Yogyakarta: Kanisius, 2010.

[5] Ben Anderson, Imagined Communities: Komunitas-komunitas Terbayang. : Yogyakarta: Pustaka Pelajar, 2008.

[6] George McTurnan Kahin, Nationalism and Revolution in Indonesia a.b Tim Komunitas Bambu. Nasionalisme dan Revolusi Indonesia. Jakarta: Komunitas Bambu, 2013.

[7] Rudolf Mrazek, Engineers of Happy Land: Perkembangan Teknologi dan Nasionalisme di Sebuah Koloni. : . Jakarta: Yayasan Obor Indonesia, 2006.

[8] R.E Elson, The Idea of Indonesia: Sejarah Pemikiran dan Gagasan. Jakarta: Serambi, 2009.

[9] Abdul Rivai, "Bangsawan Fikiran," Bintang Hindia, 1906.

[10] Pramoedya Ananta Toer, Sang Pemula. Jakarta: Hasta Mitra., 1985.

[11] Yudi Latif, Intelegensia Muslim dan Kuasa: Genealogi Intelegensia Muslim Indonesia Abad Ke-20. Jakarta: Yayasan Abad Demokrasi, $2012 \mathrm{a}$. 